\title{
Greece, Global Fault-Lines and the Disintegrative Logics of Germany's Primacy in Europe
}

\author{
Vassilis K. Fouskas \\ Professor of International Politics and Economics, School of Business \& Law, University of \\ East London, England
}

\begin{abstract}
Post-Keynesian, heterodox and Marxist political economists have rightly argued that the Eurozone crisis is not a fiscal crisis but a balance of payments crisis, mainly caused by the pivotal position of Germany in the EMU and its neo-mercantilist model of growth (low-wage, lowinflation and export-led). This view, however, sees the split between core and periphery in the EU as something created with the introduction of the EMU in 1999. This paper contends that this is not the case. By putting forth a global fault-lines historical perspective and focusing on the case of Greece, it is argued that the problem is not the introduction of the EMU but the geo-political and macroeconomic asymmetries between core and periphery in Europe since the inception of what vaguely -- and even inaccurately -- can be defined as "European modernity". Global fault-lines offer a macro-historical and macro-economic understanding of crises seen as structural events generated by the evolving and contradictory tendencies of capitalism as a world system. It is not just a political economy perspective but a perspective that encompasses many instances of the social, especially geo-political and geo-cultural, structures
\end{abstract}

\section{Introduction}

In February 1947, and in front of a group of prominent senators and General George Marshall himself, Undersecretary of State, Dean Acheson gave a passionate speech explaining why the United States must intervene in Greece, which was at the time ravaged by a bloody Civil War between Communist and nationalist forces:

If Greece fell like apples in a barrel infected by one rotten one, the corruption of Greece would infect Iran and all to the East. It would also carry infection to Africa through Asia Minor and Egypt, and to Europe through Italy and France, already threatened by the strongest Communist parties (Chase 1999, 166).

Acheson's unusual call opened the way for the Marshall Plan for the reconstruction of Europe. Greece was Acheson's template of European crisis and fixing Greece meant fixing Europe. 
For more than five years, Greece and Europe have been bleeding. As in 1947, Greece is worst of all. The country's GDP has contracted by $25 \%$, unemployment shot up to $30 \%$, and youth unemployment is currently around 60\% (Fouskas \& Dimoulas 2013). Class polarisation is visible and the political system born after the fall of the Colonels in 1974 has effectively collapsed. In October 2011, then Greek Socialist PM, George Papandreou, made an unusual international call for help and threatened to put into a referendum the country's membership of the EU. Yet no analogous plea since Acheson was made by an American official or any other ally. There was no America to help and there was no Marshall Aid, only IMF and ECB loans with usurious interest rates. So, what happened? Has Europe or Greece lost their significance for the United States? The answer cannot be positive. America needs Europe today more than ever, especially vis-á-vis the Ukrainian and Middle Eastern contingencies. But, then, what is the problem? I argue that the United States today is no longer the credit power it was in the 1940 s and 1950s and that there is a slow and protracted, yet visible and pronounced powershift to China and other emerging capitalist economies. This relative decline of Euro-Atlantic economies is the result of neo-liberal financialisation that those economies have pursued since the 1970s in order to reverse the over-accumulation crisis of the time. Herein lies the main reason why there is no Marshall Plan on the table today not just for Europe but for tiny Greece.

This contribution identifies two problematic arguments about the origins of the Greek crisis. It also identifies one good argument that needs, nevertheless, some important qualifications. The first problematic argument comes from the creditor powers and their intellectuals, arguing that the crisis is fiscal (Pagoulatos \& Triantopoulos 2010, Darvas et al.: 2011). Roughly speaking, this means that the propensity of European states to spend overexceeds their capacity and ability to collect revenues. This is the so-called "state profligacy" argument that puts the blame squarely on domestic factors and, by and large, the people. The second argument with which this contribution has serious problems is that this is a crisis of EU Treaties and the Euro as a form of world money, and that if we fix the Treaties and the acquis, then the problem will be solved (Arestis \& Sawyer: 2010). Finally, there is a third group of scholars and practitioners who have posed the most germane argument. In the words of Martin Wolf, Chief Economics Commentator of the Financial Times and celebrated financial journalist, "this is a typical balance of payments cum financial crisis and the fact that Greece was the first into trouble gave weight to the view that the crisis was fiscal" (Wolf 2013; Lapavitsas 2010; Stockhammer 2013; Lapavitsas 2013).

However, none of these arguments, including the third one, focus on the historical and geo-political origins of the Greek crisis identifying the agencies/actors behind it. And none of the arguments presented above places the crisis in a truly global context. I argue that the present crisis is a symptom of a wider, global systemic crisis bound up with the crisis of neoliberal financialization and a slow and protracted, yet steady and observable, power-shift to Asia and other emerging capitalist economies. These are processes that necessitate a "global fault-lines" approach. "Global fault-lines" is a novel, holistic framework of analysis in 
international relations and political economy that encompasses all analytical instances of the social in a macro-historical and macro-political manner. Instead of breaking-up the Hegelian/Marxist totality into various epistemic instances designating "causes" and "effects", it accepts the relative autonomy of those instances from each other as co-constitutive variables of the totality, without determination "in the last analysis" (Fouskas and Gökay 2012).

I will thus first look into the issue of the "power-shift" to Asia from a global fault-lines perspective. Then I will concentrate on the Greek debt crisis as such by way of combining historical and contemporary perspectives, thus viewing it as a symptom of those global structural forces and shifts. We will come to realise that peripheral social formations such as Greece, as well as their economic and political crises, are best analysed and understood by connecting the instances of political economy and geo-politics; in other words, a global faultlines approach is rather necessary.

\section{Crisis in the Euro-Atlantic Core and the Power-Shift to Asia}

The provenance of the financial crisis which hit the Anglo-Saxon economies in summer 2007 can be traced back to the 1970s. This was the decade of two oil-shocks, stagflation and collapse of profitability in the real economic sector and, fundamentally, President Nixon's decision to get rid of the Gold fetter (Gowan 1999, Brenner: 2003). The end of the Gold-Dollar parity and of fixed exchange rates unleashed financialisation in historically unprecedented ways (Glyn 2007, Aglietta 2008; Fine 2010; Duncan 2012): unlimited credit?? expansion and financial flows, accompanied by massive growth in the volume of global trade and FDI, including portfolio investment, asset management activity, mergers and acquisitions and extreme speculation in currency and derivatives markets. Oil trade has been peculiarly dollarised (Fouskas \& Gökay 2005). What is hiding behind the term "globalisation" is a process of extreme financialisation, that is, activity of unfettered and uncommitted capital, capital which is not conducive to real commodity production (Fouskas \& Dimoulas 2012, Epstein 2013). It is uncommitted??, "fictitious" capital. In the indebted West today, the real economic sector has receded, giving way to fictitious capital activity, speculative arbitrage, services and consumption all of which are prone to boom and bust cycles, consumer indebtedness and extreme volatility and risk. Financial capital and generalised indebtedness have permeated the daily life of Western citizenship

The second massive transformation of social and political relations, the sister-tendency of financialisation, goes under the name of neo-liberalism. This term, primarily, applies to the domestic environment of the state. For some, overcoming stagflation and the fiscal crisis of the state in the 1970s entailed the following: the welfare state must be retrenched; labour markets, banks and finance should be deregulated and state enterprises should be privatised. By "deregulation" is meant moving those agencies from state to private ownership and, in the 
case of labour unions, freeing them from state protection. This did not mean end of state interference, inasmuch as the neo-liberal state has moved to "regulation via legislation" (Sassoon 1996). Neo-liberal regimes of financial accumulation are almost entirely based on a set of complex regulations advanced by the legislative branch of the bourgeois state (Lapavitsas 2013). In this context, by the early 1980s, state elites, whether on the Left or the Right, abandoned Keynesianism, giving way to supply-side economics.

Essentially, neo-liberalism and financialisation were the responses of the West to the profitability crisis in the 1970s. Yet the failure of this strategy to restore profitability and growth rates has been spectacular; in addition, it has failed to arrest the slow and protracted decline of the Western core as a whole. This slow decline of the core goes hand in glove with the complex -- and debatable for some scholars -- ascendance of China and other emerging economies, especially after the end of the Cold War. China dominates the world market in rare earth elements (a class of minerals that are essential for electronics and computers) and has become the second largest economy in the world -- it overtook Japan in February 2011. China has become the engine driving the recovery of other Asian economies from the recessions of the 1990s. In September 2013, the British Chancellor of the Exchequer, George Osborne, rolled out the red carpet for Chinese banks looking to expand in London, making the City a significant Chinese offshore banking centre. China has already captured a large share of Africa's oil and minerals market and dominates the textiles industry in Latin America. China and India produce a combined total of more than half a million engineering and science graduates per year. The respective numbers for the USA is 60,000 . Although financialised and integrated into a global economy in which the dollar remains the key reserve currency, the real economic output of the so-called BRICs is healthy and their debt levels very low (Fouskas and Dimoulas 2013, 136).

Financialisation increased the global debt in the time span of a decade (2002-2012) in every country except China, India, Brazil, Russia and South Africa. But where do Europe and Greece figure in all this?

During the "Golden Age of Capitalism" of the 1950s and 1960s (Hobsbawm 1995), Germany re-asserted itself as Europe's economic powerhouse. As Robert Brenner and other have argued, it was mainly competition from German and Japanese capitals that drove the downward spiral of the rate of profit in the Anglo-Saxon world (Brenner 2006; Busch 1976). Germany drove the process of European integration outflanking France, something which was pointed out already in the late 1960s by such scholars as Nicos Poulantzas and Christian Palloix in France, and Elmar Altvater in West Germany (Poulantzas 1974; Palloix 1975). Soon, however, problems appeared. How to reconcile the tension between "deepening" and "widening", ie, pushing for more capitalist integration in the direction of a (federal) United States of Europe, and enlarging in consecutive steps (from 6 countries in 1957 to 27 countries in 2010)? How could the pronounced developmental gap between the core and the periphery be bridged? With a customs union at hand since the Treaty of Rome, and prompted by the 
monetary instability of the late 1960s, the Europeans pushed for monetary integration with the Werner Report of 1970. It came to naught due to American pressure, yet many in Europe at the time believed that Europe's economic space represented an "optimal currency area" - as Robert Mundell put it in a celebrated article in 1961 -- an ideal regional economy almost perfect for monetary integration (Mundell 1961). This indeed was the view that more or less dominated Europe's policy-making establishment until?? the breakout of the current crisis. Their concern has been to eliminate currency crises, exchange rate instability and risk.

This is the first fallacy, namely that uneven and deeply asymmetrical levels of economic development across Europe could be bridged by putting all currencies into the same hat and then, miraculously, levelling out uneven development and structural fault-lines by pulling the rabbit out of the hat -- the Euro, a currency lacking the political and fiscal support of a state. The second fallacy is called financialisation. From the 1980s onwards the dominant forces behind the processes of "deepening" and "widening" were other than Keynesian; they were deeply pro-monetarist, mercantilist forces: "Europe has been Hayekjacked". The emphasis, also because of pressure from Britain and the USA, was on "widening" rather than "deepening". Neo-liberalism and financialisation suited Germany very well, but one should not confuse the German model with the Anglo-Saxon one. German banks do not operate in the same way as British or American banks (Lapavitsas 2013b). The Anglo-American model is driven by consumption and debt; the German by an anti-inflationary, export-led growth regime. These differences are very significant. From the Single European Act of 1986 to the Maastricht Treaty of 1991, and from the Growth and Stability Pact of 1997 to the launch of the Euro in 1999 and after, the process of European integration has been subjected to a neo-mercantilist bias emanating from a relentless German strategy of export-led growth and wage suppression. The monetarist character of the Maastricht criteria was the result of this type of German discipline. From the mid-1990s onwards, and in order to increase profitability and price competitiveness, Germany put enormous downward pressure on wages (Stockhammer 2013)

Low wages, coupled with the institutional capacity of the German state and the dynamism of its real economic sector, magnified the existing gap between core and periphery. As we shall see, the introduction of EMU in 1999 exacerbated the asymmetries and monetary imbalances across Europe. Thus, when the global financial crisis trickled down to the Eurozone via the banking sector -- German and European banks had bought $40 \%$ of American CDOs (Collateralised Debt Obligations) and other toxic assets -- the disintegrative tendencies of the EU multiplied overnight. Greece has been and remains the weak link in Europe's and the globe's financialisation chain. This is no accident.

\section{The Greek Debt Crisis}


Greece has never been a solvent state. It always had a balance of payments problem (Fouskas \& Dimoulas 2013; Freris 1986). From its foundation in 1830 to the present day the country has almost uninterruptedly been insolvent. Note that Greece became a state thirty and forty years ahead of Italy and Germany, respectively. But this was a geo-political accident, rather than a process of ethnic homogenisation led by a robust industrial bourgeoisie. Britain and France wanted to check, deter and even block Russia's position and expansion in the Eastern Mediterranean and Egypt's penetration of the Ottoman Empire through Crete and the Peloponnese (see map). Greece was perceived as having a significant strategic value for the West, a value that outstripped the country's real economic assets.

Even before the foundation of the Greek state, the Greek elites fighting the Ottomans had declared bankruptcy. They could not finance their struggle against the Turks. Greek elites mortgaged their future land as a collateralised debt obligation for the foreign loans received. The origins of debt were political and geo-strategic, rather than economic.

This is Greece's DNA: a dependent/subaltern state in the periphery of the imperial West that always lags behind the economically and technologically advanced capitalist core. Yet, because of its position on the map, the country has always had a significant geo-strategic value. This is the country's major fault-line which is challenging to map out.

I have argued earlier that the German model of growth differs from the AngloAmerican one. The former is based on a relentless pursuit of export-led growth and antiinflation bias, whereas the latter is based on consumption and debt-driven growth. These are the two major templates across the EU, although there are more complex cases, such as that of Italy, for example (Sassoon 1986; Fouskas 1998). Greece, potentially, offers a third template against which other periphery capitalisms within the Euro-zone and beyond might be measured.

I would endeavour calling this template subaltern financialisation. Countries of the periphery recycle the financial surpluses of the core, especially of Germany, increasing their indebtedness, all the while sustaining Germany's monetarist supremacy in EMU conditions and Germany's competitiveness vis-á-vis Asian and US capitals. Greece's economic and technological progress has always lagged behind the developed core, presenting a chronic balance of payments problem. This is a structural-historical problem. But one must also be able to identify the agency perspective here. If a country imports more than it exports, then the deficit country has an over-developed layer of the population, which are the big import consortia that some scholars, such as Andre Gunder Frank and Nicos Poulantzas, called comprador bourgeoisie (Poulantzas 1974; Frank 1972). Frank's case studies in the 1960s and 1970 s concerned Latin America, but my research indicates that this, mutatis mutandis, is also the case with Greece. The comprador element has been the dominant social class in Greece. During most parts of the 19th and 20th centuries, it overwhelmed a weak capitalist industrial sector and co-determined decision-making and corrupt practices at the state-bureacratic level. But this element was in cahoots not just with the Greek government, but also with 
foreign powers and big business upon whom their welfare and comprador profits had been dependent. This is precisely what makes Greece a dependent/subaltern country in the global division of labour. But Greece has been a laggard also from a different perspective. During the "Golden Age of capitalism" in the 1950s and 1960s, the western societies experienced high wages, low inflation, almost full employment and sustained welfare and growth. Yet Greece saw nothing of this. The policy of its Central Bank was monetarist, supply-side economics prevailed and large sections of the population were excluded from political participation due to a crackdown on the Communist Left in the wake of the Civil War. When liberal democracy was restored in 1974 after seven years of dictatorship, the Right-wing government led by Constantine Karamanlis launched a Keynesian programme that clashed head on with the prevailing international trend of neo-liberal financialization. The same Keynesian policy of aggregate demand expansion was pursued by Karamanlis' socialist successor in the 1980s, Andreas Papandreou. Whereas everywhere in Europe and the West supply-side economics became the norm -- not even socialist France under Mitterrand could fight neo-liberalism as the failure of the Keynesian experiment of 1981-83 has shown -- Greece kept expanding its public sector augmenting its borrowing requirement.

One important source of the Greek debt today lies in the failure of Papandreou's cabinets to arrest the country's current account deficit by two consecutive devaluations of the drachma in the 1980s. Another is the massive domestic and external borrowing through which Greece's welfare state and nepotistic appointments in the public sector were financed (Fouskas 1997). It could be called "Keynesianism à la Greca". Greece enters the constellation of neo-liberal financialization in the mid-1990s, that is, at least 15 years later than most countries of the core, and after the collapse of Communism in its northern borders. Many at the time rushed to argue that Greece had lost its geo-strategic significance for the West and the country could plunge into debts and go bankrupt.

This prediction was wrong. Greece was very useful in the overall scheme of things, both for NATO's and the EU's processes of eastward enlargements. As Greece entered neoliberal financialisation in the second half of the 1990s under the neo-liberal "modernisation" agenda of Costas Simitis, PASOK Prime Minister from 1996 to 2004, it became a significant launching pad for the financialisation of the Balkans and the Near East, with its banks playing a major role in these two adjacent regions (Fouskas and Dimoulas 2013, $151 \mathrm{ff}$.). But was this Greek imperialism in the region? This is very doubtful. The Greek banking sector was and is completely dominated by foreign assets. More than $82 \%$ of the shares of "Greek" banks are owned by foreign individuals, insurance funds and other EU banks. Only $15 \%$ are owned by Greek interests (Union of Greek Banks 2011; Michalopoulos 2012). Therefore, the neo-liberal financialisation of Greece from the second half of the 1990s onwards served the work of core capitals and states of Europe, and above all served Germany's expansion agenda to Eastern Europe. This is what we can call subaltern financialisation and which is closely connected to geo-politics and international security. At the same time, the profile of the Greek comprador entrepreneur has changed: in the main, they now borrow heavily taking advantage of 
favourable interest rate regimes in order not just to finance the import of real commodities but, importantly, to mediate in importing fictitious commodities. Greece's financialisation is completely subordinate to the speculative activity emanating from the core. Greece registered high growth rates in the early 2000s, but this growth was debt-driven, ie based on borrowing and consumption. Within the monetary Union, which it joined in 2001, Greece and other periphery countries became more and more uncompetitive in the face of Germany's economic engine. The current Euro-zone crisis is a balance of payments crisis, although in the case of Greece, we also need to factor in its fiscal problem.

We need to go a step further. The perceived geo-political and geo-strategic importance of Greece by NATO and the EU is reflected in the structure of the country's defence budget over the years. We need to single this out of the general political economy calculations, because it is directly connected to geo-politics and geo-strategy, as well as the perceived strategic value of the country for global imperial interests.

In 2009, defence expenditure in Greece was over 3,3\% of GDP, as opposed to 2,4\% for France, 2,7\% for Britain, 2\% for Portugal, 1,4\% for Germany, 1,3 \% for Spain and 4,7\% for the USA. Between 2005 and 2009 the purchase of 26 F-16s from the USA and 25 Mirage-2000s from France represented 38\% of the total import volume of the country (Tolios: 2011, 67-68; SIPRI: 2012). Greece bought all this hard gear not with cash, but with issuing of debt. In Greece there is no such thing as a military-industrial complex, but a comprador-military complex, hence the deeply subordinate position of the country in international political economy.

\section{Concluding Remarks}

We can now draw a few conclusions.

I have argued that we can understand neither the financial crisis nor the Euro-zone crisis if we fail to embrace a historical perspective and bring in geo-politics and security as co-constitutive variables of the overall analysis. The stagflation of the 1970s and the closing of the "Gold window" by President Nixon, as Joanne Gowa put it (Gowa: 1983), is the key to understanding the unleashing of neo-liberal financialisation. This process has been driven by the great financial centres of New York and London and has transformed both the external and domestic environments of the capitalist state via boom and bust cycles, extreme financial engineering moving further away from the real economic sector. The dollarisation of the oil industry and massive improvement in defence technology, and technology and innovation, in general, are responsible for the defeat of Communism and the spread of what came to be called "globalisation". This template is based on consumption and a debt-driven growth. However, it has failed to restore profitability in the real economic sector and, significantly, it has failed to arrest the slow, complex and protracted decline of Western economies as a 
whole, a decline that has been unfolding since the Vietnam War. Our world today is multipolar rather than unipolar.

Regionalisation may be seen as an answer to Anglo-American-led neo-liberal financialisation. Indeed, under the leadership of Germany, Europe has managed to achieve a customs union and a currency union and became ambitious about Eastward and Southward expansion. But the introduction of the EMU exacerbated the developmental gap between core and periphery, further sacrificing the industrial and agricultural capacity of the periphery on the altar of the success of Germany's model of neo-liberal financialisation. This is a neomercantilist model of low inflation, low wages and high export growth, what I called the second template. The model was operational as long as Germany could recycle its trade and financial surpluses across the Euro-zone, increasing of course the debt of the periphery. This is a type of financial capital circuit and everything goes well as long as nasty crises are kept at bay. But German and European banks were exposed to Anglo-American financialisation. When the global financial crisis hit the German banks spreading the crisis to the periphery, the recycling of surpluses was interrupted and Germany began exporting to other periphery states not just cars, but also severe austerity. This is where we are at the moment.

Greece is simply a tiny little pawn in this gigantic historical picture. Her financialisation was completely subordinate to the interests of the core. But in the era of neo-liberal financialisation, its bargaining power can increase as a result of the crisis. When George Papandreou in October 2011 threatened to bring matters to a referendum, financial markets stalled. No one really knew exactly who held the mass quantities of Greek debt. At some point, Greece was on the front page of the Financial Times almost daily. For instance, if Greece had been pushed to an official default and exit from the Euro-zone, or if it had gone for a debtor-led default and exit in 2010-11, then pension funds in the United States holding Greek debt would have been unable to pay their pensioners, not to mention the possible knock-on effect that an official Greek default would have had on the European project, whatever that project is. Financial globalisation makes things very complicated. Today, of course, thanks to the official agreements that Greece's pre-Syriza cabinets have signed with the creditors, the bulk of the Greek debt is held by public institutions and banks. Under conditions of monetary union, this means that it falls on the Greek people to pay the debt for which it bears no substantial responsibility. Thus, the Left-wing Syriza party who rose to power in January 2015, is locked into the agreements made by the previous Centre-Right cabinets with the troika (IMF, ECB and the EU) and having no control of monetary policy, it is bound to accept the constraints imposed by Germany and the financial establishment that dominates the EU. Only an independent monetary policy and a new central bank issuing its own currency is in a position to create the necessary conditions for pro-Keynesian, pro-welfare policies in Greece. The same goes for the rest of European states, especially of the periphery.

As heterodox and post-Keynesian political economists have argued, the Greek and European crisis is not a fiscal crisis but rather and primarily a balance of payments crisis 
caused by the recklessness of external and domestic elites. But we have moved beyond this thesis to look at the agency and geo-strategic dimensions of the crisis. We have called the domestic elites a comprador class which has not just repeatedly failed to catch up with the core, but also has led the country to its current malaise. Whether importing real commodities, e.g. German BMWs, or fictitious commodities, e.g. AIG insurance, these idiosyncratic elites do not serve the cause of economic development and growth, let alone catching-up with the Western core. German-imposed austerity on Greece and Europe is decimating the middle classes. This is especially pronounced in Greece where party politics has become polarised, even if this is asymmetrical and the political system founded after the fall of the Colonels in 1974 is disintegrating. More than 4,000 people have committed suicide over the last four years; there are street clinics in operation and barter has become widespread; a couple of years ago, the University of Athens had suspended for a few months its operations due to lack of resources and administrative support personnel; the PASOK-ND government used to rule by decree and we do not know how the Syriza government, despite its good intentions, could rule any better if it keeps insisting on avoiding the most important debt, which is a debtor-led default and exit from the Euro-zone. The far-right, neo-Nazi Golden Dawn party, meanwhile, is making headway. One should wonder if the German Chancellor is proud of all this.

CHECK REFERENCES FOR CONSISTENCY AND WHOLE ARTICLE TO BE MADE CONSISTENT WITH HOUSE STYLE.

\section{References}

Aglietta?? (2008) 'Understanding the structured credit crisis', La Lettre du CEPII, 275, Paris: Centre d'Etudes Prospectives et d'Informations Internationales

Arestis, P. and M. Sawyer (2010) 'The problems of the economic and monetary union', The Journal of Economic Analysis (1) 1, 1-15

Brenner, R. (2003) The Boom and the Bubble. The US in the World Economy London: Verso

Brenner, R. (2006) The Economics of Global Turbulence London: Verso

Chase, James?? (1999) Acheson. The Secretary of State that Created the American World, New York: St. Martin's Press 
Darvas, Z. et al. (2011) 'A comprehensive approach to the Euro-area debt crisis', Brussels: Bruegel

Duncan, R. (2012) 'A new global depression', New Left Review, 77, 1-21

Epstein A., Gerald and M. H. Wolfson (2013) 'Introduction: The political economy of financial crisis' in Wolfson H., M and Gerald Epstein (eds) The Political Economy of Financial Crises, Oxford: Oxford University Press, 1-20

Fine, B. (2010) 'Locating financialisation', Historical Materialism, 18, 97-116

Fouskas K., Vassilis?? (1998), Italy, Europe, the Left. The Transformation of Italian Communism and the European Imperative Aldreshot: Ashgate

Fouskas K., Vassilis?? and Bülent Gökay ??(2005), The New American Imperialism. Bush's War on Terror and Blood for Oil, Connecticut: Praeger

Fouskas K., Vassilis and Bülent Gökay (2012), The Fall of the US Empire. Global Fault-lines and the Shifting Imperial Order, London: Pluto Press

Fouskas K., Vassilis and Dimoulas, Constantine (2013) Greece, Financialization and the EU. The Political Economy of Debt and Destruction New York and London: Palgrave-Macmillan

Fouskas K., V. and C. Dimoulas (2012), 'The Greek workshop of debt and the failure of the European project', Journal of Balkan and Near Eastern Studies, (14) 1, 1-33

Fouskas, K. V. (1997), 'The Left and the crisis of the Third Hellenic Republic, 1989-1997' in Sassoon, D. (ed), Looking Left London: I. B. Tauris

Frank, A. G. (1972) Lumpenbourgeoisie, Lumpendevelopment, New York: Monthly Review Press

Freris, A (1986), The Greek Economy in the 20th Century London and Sydney: Croom Helm

Glynn, A. (2007), Capitalism Unleashed Oxford: Oxford University Press

Gowa, J. (1983), Closing the Gold Window. Domestic Politics and the End of Bretton Woods, New York: Ithaca

Gowan, P. (1999), The Global Gamble. Washington's Faustian Bid for World Dominance London: Verso

Lapavitsas, C. et al. (2010) 'Euro-zone crisis: Beggar thyself and beggar neighbour', Journal of Balkan and Near Eastern Studies (12) 4, 330-368

Lapavitsas, Costas (2013) Profiting without Producing. How Finance Exploits us All, London: Verso 
Michalopoulos, G. (2012) Financing Greek Banks during the Crisis, Athens: Alpha Bank Hobsbawm, E. (1995), Age of Extremes, London: Abacus.

Pagoulatos, G. and C. Triantopoulos (2009) 'The return of the Greek patient: Greece and the 2008 global financial crisis', South European Society and Politics, (14) 1, 45-58

Palloix, C. (1975), L' internationalisation du capital, Paris: F. Maspero

Panitch, Leo and Sam Gindin (2012), The Making of Global Capitalism London: Verso

Poulantzas, N. (1974), Les classes sociales dans le capitalism aujourd'hui Paris: F. Maspero

Sassoon ??(1986), Contemporary Italy London: Longman

Sassoon, D (1996), One Hundred Years of Socialism, London: I.B. Tauris

Stockhammer, E. (2013) 'Financialization and the global economy', in Wolfson H., Martin and Gerald A. Epstein (eds) The Political Economy of Financial Crises, Oxford: Oxford University Press, 512-526

Tolios, Y. (2011), Crisis, 'Odious' Debt and Violation of Payments, Athens: Topos (in Greek) Union of Greek Banks (2011), The Greek Banking System Athens: UGB

Wolf, M (18 June 2013) 'The toxic legacy of the Greek crisis', Financial Times 